\title{
Aneursymal Bone Cyst Causing a Femoral Neck Fracture: A Pediatric Case
}

\author{
Anevrizmal Kemik Kistine Bağlı Femur Boyun Kırrğl: Pediatrik Olgu Sunumu
}

\author{
Mithat Öner', Emre Yurdakul', Polat Durukan² \\ 'Department of Ortopedics, Faculty of Medicine, Erciyes University, Kayseri, Turkey \\ ${ }^{2}$ Department of Emergency, Faculty of Medicine, Erciyes University, Kayseri, Turkey
}

\begin{abstract}
Aneurysmal bone cysts are benign active or aggressive bone lesions that commonly arise in the long bones, especially the femur, tibia and humerus and in the posterior elements of the spine. They are extremely rare, occurring in 1.5 per one million people per year. They most commonly occur in the metaphysis of long bones during the first two decades of life and usually present with pain, swelling or fracture. The etiology of aneursymal bone cysts is unknown, but numerous authors have proposed that they form in response to vascular disruption in the bone due to a pre-existing primary tumor or a traumatic insult. The early rate of growth of aneursymal bone cysts is also unknown. We wanted to share this case to show the destructive effects of aneursymal bone cysts.
\end{abstract}

Keywords: Bone cyst, femoral neck fracture, curettage Received: 17.12.2011 Accepted: 22.02.2012

\section{ÖZET}

Anevrizmal kemik kisti, iyi huylu, genişleme özelliği olan, daha çok çocukluk ve adölesan çağlarda görülen kemik lezyonlarıdır. Özellikle femur, tibia, humerus gibi uzun kemikler ve vertebra posterior elemanlarına yerleşir.Yaklaşık yılda 1.5 milyon insan bu hastalığa maruz kalmaktadır. Herhangi bir kemik segmentini tutabilmekle birlikte en sık tutulum alanları uzun kemikler ve vertebraların metadiyafizleridir. Etyolojide hala fikir birliği sağlanamamıştır. En güçlü kabul edilen görüş kemiğe gelen mikrotravmaların kemiğin dolaşımını bozduğu kabul edilmektedir. Tedavi seçeneğine hastanın şikayeti, lezyonun lokalizasyonu ve büyüme hızına göre karar verilir. Kliniğimizde teşhis ve tedavisini yaptığımız bu vakayı hastalığın sinsi ve yıkıcı etkilere yol açabileceğini vurgulamak amacı ile meslektaşlarımızla paylaşmayı amaçladık.

Anahtar Kelimeler: Kemik kisti, femur boyun kırı̆̆ı, küretaj Geliş Tarihi: 17.12.2011 Kabul Tarihi: 22.02.2012

\section{Introduction}

Aneurysmal bone cysts $(A B C)$ are benign active or aggressive bone lesions that commonly arise in the long bones, especially the femur, tibia, and humerus and in the posterior elements of the spine (1,2). They are extremely rare, occurring in 1.5 per one million people per year. They most commonly occur in the metaphysis of long bones during the first two decades of life and usually present with pain, swelling or fracture. The etiology of $A B C$ is unknown, but numerous authors have proposed that they form in response to vascular disruption in the bone due to a pre-existing primary tumor or a traumatic insult (3). The early rate of growth of $A B C$ is also unknown.

\section{Case Report}

A 14-year-old boy suffered from a left femoral neck fracture in July 2010 while playing football. He was previously healthy, and presented to the outpatient clinic with a complaint of hip pain of four weeks in duration (Figure 1). He also complained of pain over his left hip region, which was dull, aching, non-radiating, continuous, and which increased with walking and was associated with a limp. The patient walked with an antalgic gait and pointed out numbness over his left thigh which radiated along the lateral aspect of the thigh. The movement and power of the left hip were normal except for pain during wide abduction. There was no history of fever, chronic illness or swelling in other body regions. The blood analysis, including a complete blood count, erythrocyte sedimentation rate, liver and renal function tests, fasting blood sugar levels and coagulation profile were normal. There 
was no clear initiating factor, such as trauma. There were no other symptoms or complaints. Intraoperative evaluation showed an approximately $8 \times 4 \mathrm{~cm}$ mass over his left hip region. It was a highly vascular lesion with multiple blood-filled cavities. The liquid-liquid level (shown by black arrows) was significant within the medullary canal. He was treated with open reduction, wide margin curettage (debulking) for preserving hip stability and preventing recurrence. The defect was replaced with an allograft stabilized by means of a DHS plate (Figure 2). The fracture healed uneventfully and by 2010 December, the fracture had healed radiographically and he had returned to all activities without any pain or limitations within 12 weeks of surgery.

\section{Discussion}

Jaffe and Lichtenstein first described $A B C$ as a distinct pathologic lesion in $1942(1,3)$. Biesecker et al. observed that 32\% of their cases were associated with other benign lesions of the bone $(1,3,4)$. The precise pathogenesis of $\mathrm{ABC}$ is unclear, although theories ranging from post-traumatic bone alteration, reactive vascular malformation and genetic predisposition have been described (5). The most widely accepted pathogenic mechanism for the development of $A B C$ involves a hypothetical local circulatory disturbance that leads to markedly increased venous pressure and the development of dilated and enlarged vascular elements within the affected bone (6). A few case reports in the last decade have lent further support to Biesecker's theory (3). They have confirmed the presence of a posttraumatic $A B C$ following an injury in which initial $x$-rays showed no suggestion of a bone lesion. In one case, an $A B C$ developed at the fracture site in the proximal tibia within six months of the injury. In all of these cases, the tumor appeared at the local site of injury, suggesting that the injury led to the formation of the lesion. In some cases, it has been reported that radical wide resection of primary tumors and reconstruction with appropriately rigid prosthetic material are necessary to avoid instability and to minimize local recurrence (7-9). In this case, we show that the most common and effective procedure is curettage with/without grafting. However, high recurrence rates have been reported, from 10 to 59\%. Ozaki et al. reported 17\% recurrence rates with curettage and cement application $(8,10,12,13)$. In the same study, the results were compared with cryotherapy and lower complication rates were found in the cement group. The advantages of this technique are that it is easy to perform and the cement provides structural support in the cavity. However, it has limitations, as neurovascular structures and the growth plate should be protected from the heat generated with this technique. Good results (between $82-96 \%$ success) have been reported with cryotherapy $(11,12)$

However, progression of fractures, local infection, fusion or nerve damage with associated fractures and growth plate destruction are potential complications $(11,12)$. Corticosteroid injections are ineffective in the treatment of aneursymal bone cysts (11). Although radiotherapy has been used in the treatment of $A B C$ in doses between 30-40 Gy to ossify cysts, it is not usually preferred due to various complications such as osteonecrosis, shortening, gonad damage and sarcoma (9-11). Some case reports have employed intralesional injection of calcitonin and methylprednisolone for the treatment of $A B C$. This method is safe and effective, and is an important alternative to surgery, especially when a surgical procedure is technically difficult or unsafe in high-risk patients (11).

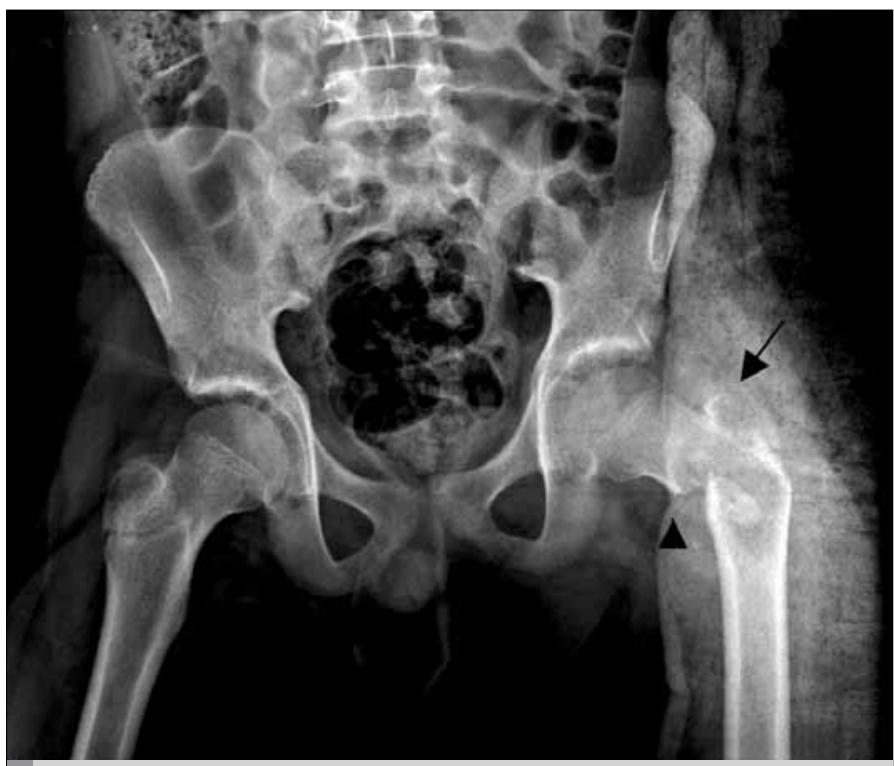

Figure 1. AP x-rays after injury

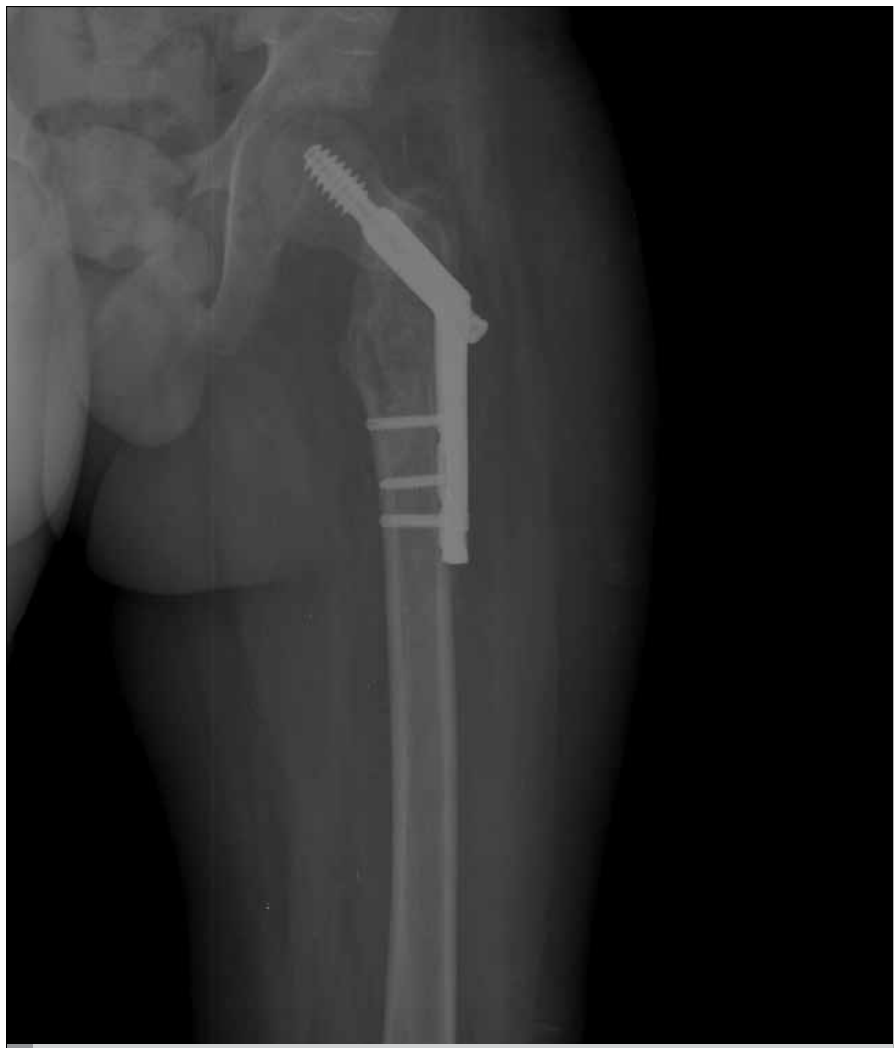

Figure 2. AP x-ray after 8 week demonstrating an eccentric, geographic lytic lesion in the proximal femoral metaphysis

\section{Conclusion}

$A B C$ is a rare benign bone tumor that presents primarily in the first two decades of life and exhibits a slight female predominance. Rapid and silent progression is the most important quality of $A B C$. The ideal treatment plan includes effective curettage through broad exposure in addition to grafting and rigid internal fixation. 


\section{Conflict of interest}

No conflict of interest was declared by the authors.

\section{References}

1. DiCaprio MR, Murphy MJ, Camp RL. Aneurysmal bone cyst of the spine with familial incidence. Spine 2000; 25: 1589-92. [CrossRef]

2. Schonauer $\mathrm{C}$, Tessitore $\mathrm{E}$, Schonauer M. Aneurysmal bone cyst of the frontal bone in a soccer player. Acta Neurochir (Wien) 2000; 142: 1165-6. [CrossRef]

3. Biesecker JL, Marcove RC, Huvos AG, Miké V. Aneurysmal bone cysts. A clinicopathologic study of 66 cases. Cancer 1970; 26: 615-25. [CrossRef]

4. Jaffe HL. Aneurısymal bone cyst. Bull Hosp Joint Dis 1950; 11: 3-13.

5. Althof PA, Ohmori K, Zhou M, Bailey JM, Bridge RS, Nelson M, et al. Cytogenetic and molecular cytogenetic findings in 43 aneurysmal bone cysts: aberrations of $17 p$ mapped to $17 p 13.2$ by fluorescence in situ hybridization. Mod Pathol 2004; 17: 518-25. [CrossRef]

6. Chan G, Arkader A, Kleposki R, Dormans JP. Case report: primary aneurysmal bone cyst of the epiphysis. Clin Orthop Relat Res 2010; 468: 1168-72. [CrossRef]

7. Montalti M, Alberghini M, Ruggieri P. Secondary aneurysmal bone cyst in fibrous dysplasia of the proximal femur. Orthopedics 2009; 32: 363. [CrossRef]
8. Beris AE, Lykissas MG, Payatakes A, Kontogeorgakos VA, Mavrodontidis A, Korompilias AV. Free vascularized fibular graft for treatment of pathological femoral neck fracture and osteonecrosis of the femoral head: a case report with a long-term follow-up. Microsurgery 2009; 29: 240-3. [CrossRef]

9. Singh VP, Mir R, Kaul S. Aneurysmal bone cyst of sternum. Thorac Surg 2010; 89: e43-5. [CrossRef]

10. George B, Abudu A, Grimer RJ, Carter SR, Tillman RM. The treatment of benign lesions of the proximal femur with non-vascularised autologous fibular strut grafts. J Bone Joint Surg Br 2008; 90: 648-51.

11. Ohashi M, Ito T, Hirano T, Endo N. Percutaneous intralesional injection of calcitonin and methylprednisolone for treatment of an aneurysmal bone cyst at C-2. Division of Orthopedic Surgery, Department of Regenerative and Transplant Medicine, Niigata University Graduate School of Medicine and Dental Sciences, Niigata, Japan. J Neurosurg Pediatr 2008; 2: 365-9.

12. Yildirim E, Ersözlü S, Kirbas I, Özgür AF, Akkaya T, Karadeli E. Treatment of pelvic aneurysmal bone cysts in two children: selective arterial embolization as an adjunct to curettage and bone grafting. Diagn Interv Radiol 2007; 13: 49-52.

13. Ozaki T, Hillmann A, Lindner N, Winkelman W. Cementation of primary aneurysmal bone cysts. Clin Orthop Relat Res 1997; 337: 240-8. 